\title{
Exploring Face Chart Module Development in Enhancing Students' Maquillage Skills: A Case Study
}

\author{
Mayaslinda Mahayudin, Azidah Abu Ziden* \\ School of Educational Studies, University Sains Malaysia, Malaysia
}

Received June 1, 2020; Revised July 18, 2020; Accepted August 10, 2020

\section{Cite This Paper in the following Citation Styles}

(a): [1] Mayaslinda Mahayudin, Azidah Abu Ziden, "Exploring Face Chart Module Development in Enhancing Students' Maquillage Skills: A Case Study," Universal Journal of Educational Research, Vol. 8, No. 9, pp. 4097-4104, 2020. DOI: 10.13189/ujer.2020.080935.

(b): Mayaslinda Mahayudin, Azidah Abu Ziden (2020). Exploring Face Chart Module Development in Enhancing Students' Maquillage Skills: A Case Study. Universal Journal of Educational Research, 8(9), 4097-4104. DOI: 10.13189/ujer.2020.080935.

Copyright $(2020$ by authors, all rights reserved. Authors agree that this article remains permanently open access under the terms of the Creative Commons Attribution License 4.0 International License

\begin{abstract}
An epidemic of COVID-19 has expanded and spread all over the world. Until today no vaccine has been found to protect ourselves from being infected by the COVID-19 virus. Therefore, the World Health Organization (WHO) has outlined some guidelines for the community to avoid this infectious virus including keeping a 1-meter social distance and avoiding physical contact with others. Hence, this study aimed to provide students with independent ongoing training in the art of maquillage skills particularly in blending techniques using face charts through the module development. The module has been developed for a course in a Vocational College in Malaysia to assist students in practising the blending of colours in maquillage. Qualitative case studies have been used to obtain in-depth information on the progress of students' skills in blending techniques. The assessment rubric was used as a research instrument to assess students' abilities in 3 attributes of colour in the blending techniques. Semi-structured interviews were also used in this study to get responses from participants about the effectiveness of module implementation. The 4 participants were involved in practising blending techniques using the module. Findings of the study show that students' skills in applying blending techniques were moderate during the early stage of training but their skills improved during the second and third stages after the students were more comfortable with the blending techniques. It is suggested that in this study, students' skills in maquillage could be developed through systematic ongoing training and structured modules.
\end{abstract}

Keywords Vocational Education, Art Education, Maquillage Skills, Blending Technique, Face Chart

\section{Introduction}

An epidemic of COVID-19 has been spreading all over the world [1]. Many industries all over the world are forbidden from operating and people are ordered to stay at home to prevent the spread of COVID-19 virus. Similarly, educational institutions were seriously affected by schools, colleges, and universities' operations temporarily stopped and resulting in disruption to the teaching and learning process. Hence, online learning nowadays is considered a mandatory alternative for teachers to convey their teaching and learning resources [2]. This effort is a major challenge for educators, especially those in the field of vocational education involving direct skills that are difficult to apply online. Since no vaccine has yet been found to protect against COVID-19 virus infection, the World Health Organization (WHO) has set new norms for the world community to avoid being infected such as maintaining a 1-meter social distance with others and avoiding physical contact with others [3]. Therefore, this research has developed a maquillage skills training module which will provide a complete guide for students to practise maquillage techniques independently without involving paired exercises or training with classmates. 
One of the specific techniques on maquillage skills that the student needs to master is blending techniques. Blending techniques are needed in maquillage applications and are the most basic in cosmetology skills [4,5]. However, student's blending techniques are considered poor because of a lack of knowledge and skills about the maquillage technique and principle. As in other studies, there are some weaknesses of systematic 3D maquillage training [5]. Teaching methods such as demonstration seem to have less impact because of the difficulty of understanding the technique through observation. Besides that, studies also suggest that some students may not be able to focus on the demonstration presented by the instructor because each student has a different level of ability to absorb the knowledge presented, making the program participants' maquillage work less satisfactory $[5,6]$. Students not only learn through observation but must also learn by doing, using their senses to engage in learning activities to get more experience $[6,8,9]$. It is also suggested that students who have not been taught blending techniques properly, result in them being unable to produce a good and even maquillage application. Research by Aytug [10] and Setiawardani and Suhartiningsih [11] found that there are students who are not exposed to techniques and knowledge of stage maquillage and they also do not have maquillage knowledge on shading and brightness during facial contouring.

In this study, the blending technique is developed using the face chart module. Good maquillage skills need a good hands-on consistency called blending technique. Blending technique is a primary skill to produce even beauty maquillage through blending and mixing the colour edges smoothly. Hence, this study aims to identify the level of participant skills in conducting blending techniques through continuous practices using a face chart.

\section{Background}

\subsection{Maquillage Skills}

Maquillage is a French word meaning makeup application. The term maquillage refers to the camouflage makeup commonly used by the actress to mimic faces of various colours and concepts [12]. Maquillage skills are similar to the skills of an artist but use the human body as a canvas to paint a work of art $[13,14]$. Mastering the maquillage skills makes students more competent in controlling brushes and colours during application. Various methods have been used by the lecturer to ensure students can apply their maquillage skills splendidly. However, in this study, the researcher used a continuous training method for blending techniques on the face chart, aimed at improving the students' maquillage skills.

\subsection{Blending Technique and Face Chart Module Development}

Blending technique is a maquillage skill using the maquillage apparatus and substance to balance colours evenly without showing the difference between shades [11]. An important skill in making fine maquillage is the technique of blending colours and lines [13]. This technique involves the control of movement and pressure of the brush in the right way, resulting in uniform colour on all surfaces. Therefore, the blending technique is an important technique that students need to master in order to create beautiful and perfect maquillage.

In this study, researchers employ a colour theory in the module to enhance the blending technique in maquillage skills. The researchers extracted 3 attributes from the theory to obtain the real blending technique in a practical context. The 3 attributes to improve students' skills in applying the blending technique are hue, value, and intensity.

The module has 3 activities that combine these 3 attributes to train students' skills in blending techniques. Activity 1 is a line chart exercise that gives students training in applying colour blending into three types of lines. Activity 2 involves the exercise of blending colours in shape diagrams and activity 3 involves the exercise of blending colours for facial contouring using facial anatomy charts.

The findings of this study can help students to apply the doable knowledge for maquillage application in a practical manner. The attributes of the colour theory help students to deliver the blending technique efficiently. Besides that, this study can be an additional method for teachers to deliver the best input for students to carry out their maquillage application at home.

\subsection{Attributes of Colour Theory (Hue, Value, and Intensity)}

Hue, the first attribute of colour with an ordinary typical name is base or pure colour [14]. Hue is closely related to the selection of foundation colours to match skin tone. For instance, beige and ivory reflect on brown hue skin tone, thus colour contras that occur from the two attributes of value and intensity alter accordingly. Therefore, the three attributes of colour which are hue, value, and intensity move integratedly to produce an even and neat maquillage blending. This study used hue as a base skin tone in the maquillage blending technique for basic maquillage activity to develop students' skills in applying colour foundation. 


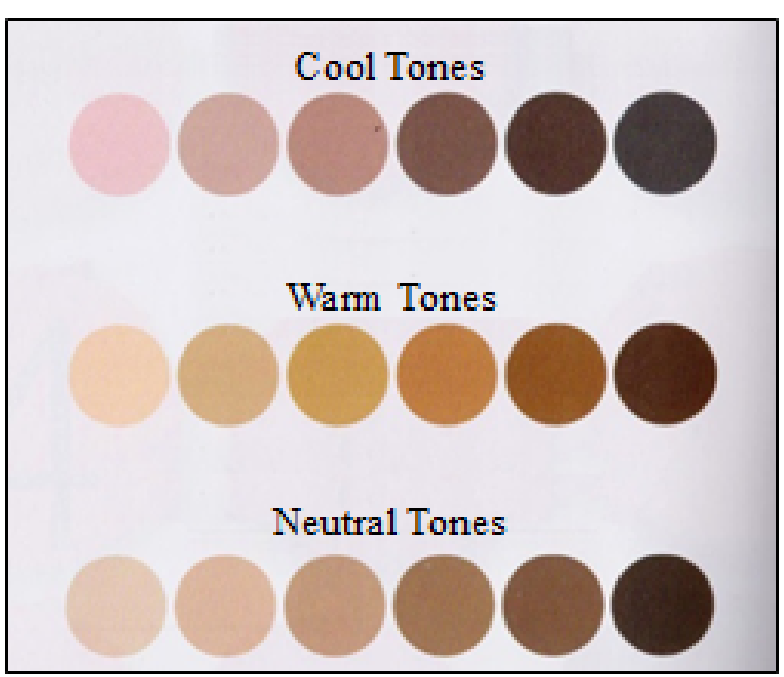

Figure 1. Maquillage Base Colours (Middleton, 2018)

Figure 1 shows three groups of hues in determining a suitable foundation colour match. Each hue is precisely arranged based on identical skin tones to result in a good foundation colour match.

Value, the second attribute of colour is included in the blending technique implementation. Value refers to the choice of hue colour on the same value scale [15]. The selection of hue in the same value scale is to ensure the right skin tone is picked. In the process of blending, the colour value should be controlled consistently in the same colour hue scale to get a three-dimensional effect in face contouring activity. This study used the value attribute from colour theory to improve the students' skills in blending techniques.

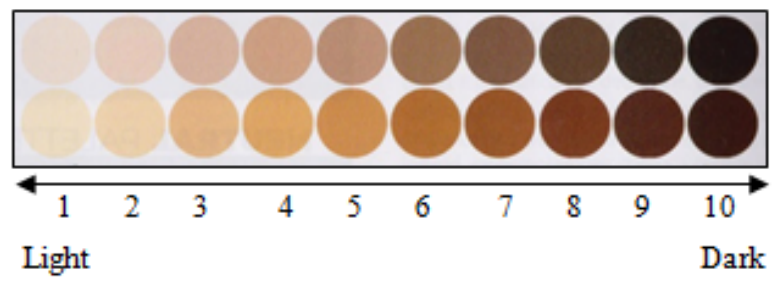

Figure 2. Value Colour Scale (Middleton, 2018)

Figure 2 shows two groups of value colour scale in ten of tone from dark to light. In this study, students should only use the same value colour on the same scale and blend them accordingly to produce even contouring applications.

Intensity is the third attribute of colour that is integrated with hue and value to complete the blending technique implementation. Intensity related to the colour vividness and colour saturation point determines the quality of light in colour [16]. However, in the context of blending technique, the intensity is practically used to control equality of colour with the right amount of colour and avoids spots and dots in parts.

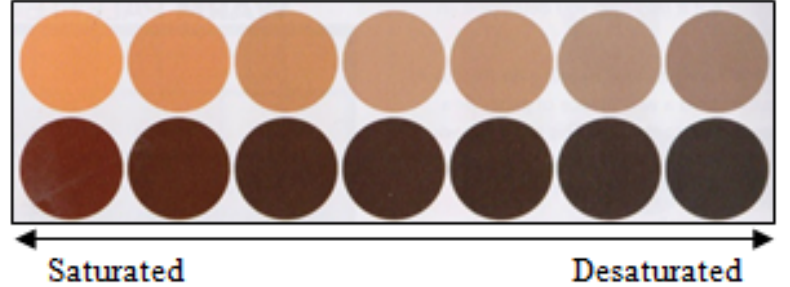

Figure 3. Colour Intensity (Middleton, 2018)

Figure 3 shows a colour intensity scale from desaturated to saturated. This study used colour intensity for students' skills in applying blending techniques in the context of controlling colour saturation point. A good saturation point is full of saturated colour. The best desaturation point is full of desaturated colour.

\subsection{Face Chart}

The face chart paper is used as a real face substitute for training activities in the module. A face chart is a piece of drawing paper that has a sketch of a face shape to represent the original face, the module looking like a colouring book to apply makeup with certain concepts [17]. In this study, the face chart is used by students as a substitute for real faces to carry out the activities in the module. Previously, students applied makeup to the face of their classmates during the training period, which resulted in skin damage and acne as well as disruption to a smooth teaching and learning process in the classroom. Additionally, this facial chart method is used to avoid physical contact with classmates who can cause COVID-19 virus infection. Therefore, researchers used face charts as face simulator or medium to solve the problem of physical contact in this pandemic. The experiential learning method using a simulator or model in learning activities can be used when there are obstacles in real situations [6]. Therefore, the researcher uses a face chart in the module as a medium for blending exercises.

\section{Materials and Methods}

This research used a case study design with a qualitative approach. A case study is a method that deals with investigating the actual events that occur with in-depth information [18]. Three attributes in the blending technique are closely observed and evaluated to determine the level of students' proficiency in the application of blending techniques. This case study involved Community College students in Perak from the 3rd-semester beauty therapy and spa program. The study was conducted in 3 days with 2 hours a day, to train students in blending technique application on a face chart. Document analysis was used as a research data collection method to evaluate the participants' artwork in the application of blending techniques, to avoid researchers and lecturers from close physical contact with participants. Therefore, the activities 
in this module allowed participants to practise on their own to avoid physical contact with their classmates. Besides, the semi-structured interview was used to get responses from students about the module implementation.

\subsection{Sample}

The purposive sampling in this study involved 4 participants with poor maquillage skills. They voluntarily agreed to participate in this program. The participants were college students in their second semester. All the participants were female students aged between 18 and 19 years.

\subsection{Instrument}

This study used two types of instruments for data collection: document analysis and semi-structured interviews to get a real picture of the level of participant's skills in blending techniques. Document analysis was used to evaluate the artwork of the maquillage that was applied to the face chart. Three attributes, hue, value, and intensity, were evaluated using the maquillage artwork assessment rubric to determine the level of maquillage skills in the blending technique after undergoing the exercises. The rubric used three scores, 5 for good level, 3 for moderate level, and 1 for low level. The researchers adapted the rubric from the beauty and spa therapy program curriculum of the Department of Community College Studies. Table 1 shows the maquillage artwork assessment rubric. Assessment is based on 3 attributes in the blending technique that is hue, value, and intensity. Each attribute is ranked in three levels; good, moderate, and weak each with a score of 5, 3, and 1 respectively. Score 5 is given for very neat and even maquillage, while score 3 is given for less neat and less even maquillage, while Score 1 is given for untidy and uneven maquillage.

\subsection{Treatment (implementation)}

Blending technique exercises using the face charts were carried out for 3 days. Each day, participants were exposed to blending techniques exercise for 2 hours. In a total of 6 hours, participants were taught the blending technique. The final artwork of the participants in the class was later submitted to the lecturer for evaluation.

Table 2 shows the duration of conducting the study of blending technique training.

The activity was conducted in 3 days involving blending technique exercises. During these exercises, participants were provided with a blank face chart with an anatomy face chart and QR code to access the video tutorial provided in the module to help students to apply the blending technique by themselves in class. Participants practised by applying and blending colours to the face charts provided using the blending technique while watching the tutorial video. Hence, the ongoing practice during this activity enabled the researchers to determine the level and consistency of the blending skills of the participants. The researchers evaluated the final artwork using the face charts based on the three attributes which are hue, value, and intensity. Figure 4 shows the activity in the module that offered a face chart with anatomy lines for students to do the exercise.

Table 1. Maquillage artwork assessment rubric

\begin{tabular}{|c|c|c|c|c|}
\hline \multirow{2}{*}{ NO. } & CRITERIA & $\mathbf{5}$ (Good) & $\mathbf{3}$ (Moderate) & 1 (Low) \\
\cline { 3 - 5 } & $\begin{array}{c}\text { Hue } \\
\text { Basic colour in the face } \\
\text { chart }\end{array}$ & $\begin{array}{c}\text { Blending hue very neatly } \\
\text { and evenly }\end{array}$ & $\begin{array}{c}\text { Blending hue less neatly and } \\
\text { less evenly }\end{array}$ & $\begin{array}{c}\text { Blending hue untidily and } \\
\text { unevenly }\end{array}$ \\
\hline 2. & $\begin{array}{c}\text { Value } \\
\text { Mixing brightness and } \\
\text { darkness colour in the } \\
\text { same value scale }\end{array}$ & $\begin{array}{c}\text { Blending brightness and } \\
\text { darkness colour in the same } \\
\text { value scale, very neatly and } \\
\text { very evenly }\end{array}$ & $\begin{array}{c}\text { Blending brightness and } \\
\text { darkness colour in the same } \\
\text { value scale, less neatly and less } \\
\text { evenly }\end{array}$ & $\begin{array}{c}\text { Blending brightness and darkness } \\
\text { colour in different value scale, } \\
\text { untidily and unevenly }\end{array}$ \\
\hline 3. & $\begin{array}{c}\text { Intensity } \\
\text { Mixing colour } \\
\text { saturation }\end{array}$ & $\begin{array}{c}\text { Blending colour saturation } \\
\text { very neatly and very evenly }\end{array}$ & $\begin{array}{c}\text { Blending colour saturation less } \\
\text { neatly and less evenly }\end{array}$ & $\begin{array}{c}\text { Blending colour saturation untidily } \\
\text { and unevenly }\end{array}$ \\
\hline
\end{tabular}

Table 2. Schedule of the treatment

\begin{tabular}{|c|c|c|}
\hline Day & Time & Activity \\
\hline 1. & 2 hours & \\
\cline { 1 - 2 } 2. & $11.00 \mathrm{am}-1.00 \mathrm{pm}$ & Face chart \\
(blending colour)
\end{tabular}




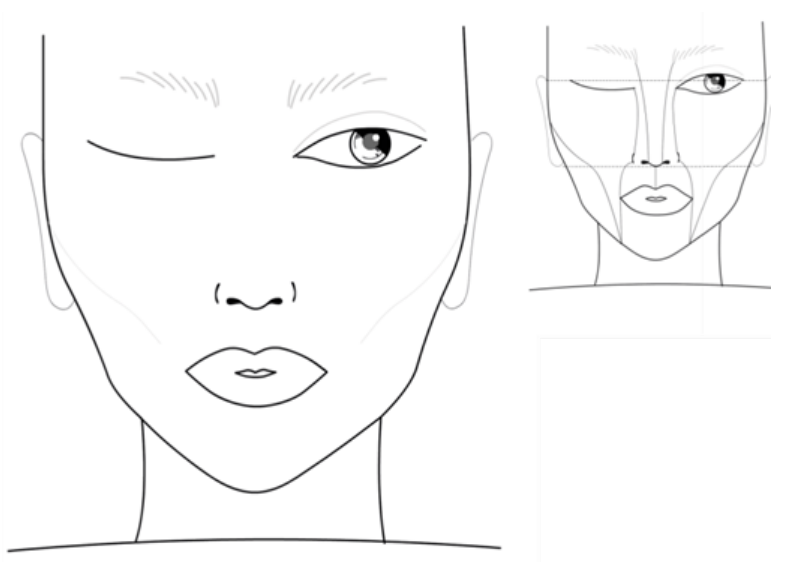

Figure 4. Blank face chart

\section{Results}

The level of the skills was assessed through 3 attributes of colour, namely hue, value, and intensity. The assessment rubric was used to determine the level of participant's skills during the application of the blending technique with the scores of 5 for good, 3 for moderate, and 1 for weak. Evaluation from two lecturers was used to ensure the reliability of the research findings and avoid researcher bias. Meanwhile, the interview session was done for data triangulation besides obtaining in-depth information about the module's effectiveness in the context of ongoing training.

The findings show that the level of participant's skills was at a good level with very neat and even colour blending. The results indicate that the consistency of colour control had improved.

Figure 5 shows the results of the participant's maquillage application on the face chart. The results showed that participants were able to apply colours splendidly and were able to integrate the attributes of hue, value and intensity into their maquillage skills.

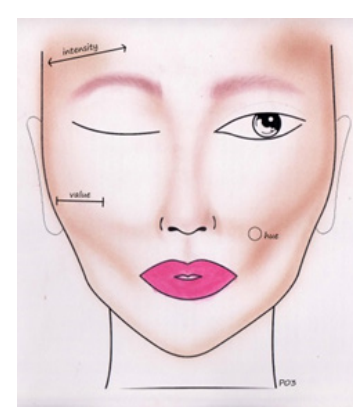

P01

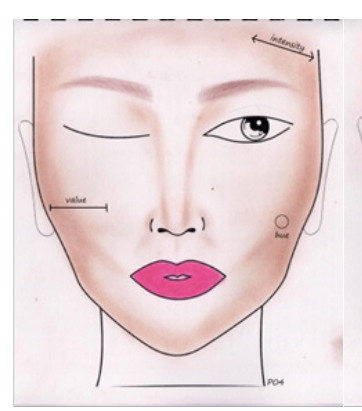

$\mathrm{P} 02$

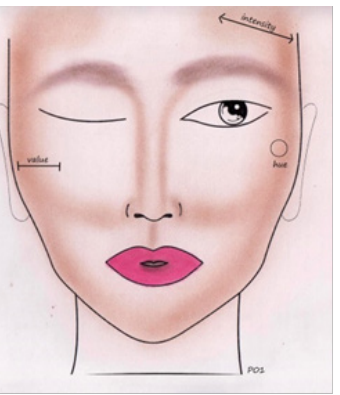

$\mathrm{P} 03$

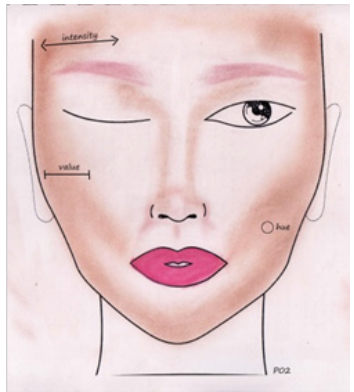

P04

Figure 5. Participant's maquillage artwork on the face chart

Table 3. Data analysis for maquillage artwork assessment score

\begin{tabular}{|c|c|c|c|c|c|c|c|}
\hline \multirow{3}{*}{ No. } & \multirow{3}{*}{ Participant } & \multicolumn{6}{|c|}{ Assessment score } \\
\hline & & \multicolumn{2}{|c|}{$\begin{array}{c}\text { Hue } \\
\text { Mixing basic colour is ... }\end{array}$} & \multicolumn{2}{|c|}{$\begin{array}{c}\text { Value } \\
\text { Mixing bright and dark colours in } \\
\text { the same value scale is ... }\end{array}$} & \multicolumn{2}{|c|}{$\begin{array}{c}\text { Intensity } \\
\text { Mixing colour saturation is... }\end{array}$} \\
\hline & & Lecturer A & Lecturer B & Lecturer A & Lecturer B & Lecturer A & Lecturer B \\
\hline 1. & P01 & $\begin{array}{c}5 \\
\text { very neat and } \\
\text { even }\end{array}$ & $\begin{array}{c}5 \\
\text { very neat and } \\
\text { even }\end{array}$ & $\begin{array}{c}5 \\
\text { very neat and } \\
\text { even }\end{array}$ & $\begin{array}{c}3 \\
\text { less neat and } \\
\text { uneven }\end{array}$ & $\begin{array}{c}3 \\
\text { less neat and } \\
\text { uneven }\end{array}$ & $\begin{array}{c}3 \\
\text { less neat and } \\
\text { uneven }\end{array}$ \\
\hline 2. & P02 & $\begin{array}{c}5 \\
\text { very neat and } \\
\text { even }\end{array}$ & $\begin{array}{c}5 \\
\text { very neat and } \\
\text { even }\end{array}$ & $\begin{array}{c}3 \\
\text { less neat and } \\
\text { uneven }\end{array}$ & $\begin{array}{c}5 \\
\text { very neat and } \\
\text { even }\end{array}$ & $\begin{array}{c}3 \\
\begin{array}{c}\text { less neat and } \\
\text { uneven }\end{array} \\
\end{array}$ & $\begin{array}{c}3 \\
\begin{array}{c}\text { less neat and } \\
\text { uneven }\end{array} \\
\end{array}$ \\
\hline 3. & P03 & $\begin{array}{c}5 \\
\text { very neat and } \\
\text { even }\end{array}$ & $\begin{array}{c}5 \\
\text { very neat and } \\
\text { even }\end{array}$ & $\begin{array}{c}5 \\
\text { very neat and } \\
\text { even }\end{array}$ & $\begin{array}{c}5 \\
\text { very neat and } \\
\text { even }\end{array}$ & $\begin{array}{c}5 \\
\text { very neat and } \\
\text { even }\end{array}$ & $\begin{array}{c}5 \\
\text { very neat and } \\
\text { even }\end{array}$ \\
\hline 4. & P04 & $\begin{array}{c}5 \\
\text { very neat and } \\
\text { even }\end{array}$ & $\begin{array}{c}5 \\
\text { very neat and } \\
\text { even }\end{array}$ & $\begin{array}{c}5 \\
\text { very neat and } \\
\text { even }\end{array}$ & $\begin{array}{c}5 \\
\text { very neat and } \\
\text { even }\end{array}$ & $\begin{array}{c}5 \\
\text { very neat and } \\
\text { even }\end{array}$ & $\begin{array}{c}5 \\
\text { very neat and } \\
\text { even }\end{array}$ \\
\hline
\end{tabular}

Score indication: $5=$ Good $3=$ Moderate $\quad 1=$ Weak 
Table 3 shows the analysis data for the assessment of the participant's maquillage artwork performed on the face chart. A corresponding evaluation was carried out based on the 3 attributes of the blending technique, which are hue, value, and intensity. The table shows the assessment given by the two lecturers.

\subsection{Maquillage Artwork Assessment}

\subsubsection{Hue}

The hue attribute is assessed based on the selection of basic colours. This study found that the hue attribute in maquillage artwork on face charts of P01, P02, $\mathrm{P} 03$ and $\mathrm{P} 04$ at a good level with a score of 5 given by lecturer A and lecturer $\mathrm{B}$. The artworks on the face chart by $\mathrm{P} 01, \mathrm{P} 02$, $\mathrm{P} 03$, and P04 are very neat and even in terms of hue blending.

\subsubsection{Value}

The value attribute is evaluated based on the blending of dark and bright colours on the same value scale. The findings show that the maquillage artwork on face charts by $\mathrm{P} 01$ was good with a score of 5 given by lecturer $\mathrm{A}$ because the value scale of dark and bright colours was very neat and evenly blended. Contradictory to that assessment, lecturer B gave a score of 3 for satisfactory maquillage performance for $\mathrm{P} 01$ 's value attribute. Meanwhile, analysis of the research data found that lecturer A gave a score of 3 to P02 because the artworks had a mixture of dark and bright colours on the same scale but were less neat and less evenly distributed. Lecturer B's evaluation with a score of 5 , found that the artwork on P02's face chart on the value attribute was very neat and even. For $\mathrm{P} 03$ and P04, the results show that artwork on the face chart has a mixture of dark and bright colours on a very neat and uniform scale, with a score of 5 given by both lecturer A and lecturer B for $\mathrm{P} 03$ and $\mathrm{P} 04$.

\subsubsection{Intensity}

The intensity attribute is evaluated based on perfecting a neat and even colour saturation. The study found that lecturer A and lecturer B rated the artworks on P01 and
P02's face charts were at a moderate level with a score of 3 due to less neat and uneven colour saturation. Evaluation of final maquillage artwork on P03 and P04's face charts showed the same good score of 5 was given by lecturer A and lecturer B because the colour saturation results were very neat and even.

\subsection{Interview}

Interview sessions were conducted after the completion of the module training activities via voice recording to avoid the frequency of face-to-face meetings with the participants. The findings were based on four categories to show the participant's feedback on the module implementation. The table below shows the categories, interview questions, and quotations that have been analyzed from the interview data.

Table 4 shows the thematic analysis of the interview session. There are four categories in the data collection. Participants found that the content of the modules arranged step-by-step to guide students enabled them to carry out their activities more efficiently. The participants also explained that the information contained in the video tutorial helped them to better understand the methods of applying colour blending techniques. The participants also said that the more structured guides and instructions for the facial contouring activities such as anatomical lines on the cheeks and nose made it easier for the students to follow when learning facial contouring techniques. Besides that, the participants also responded positively to the role of the module in solving skin problems due to direct application of make-up to the face during exercises. Participants agreed that the face chart concept used in this module can prevent students from using real faces for practice and at the same time, they can continue to practice consistently using face charts. Participants added that learning with the assistance of the video tutorial was easier than referring to long, thick, and heavy notes. They also found that the video tutorials also made it easier for them to understand the techniques in practical contexts compared to reading the difficult notes. 
Table 4. Thematic analysis for interview data

\begin{tabular}{|c|c|c|}
\hline No. & Categories & Question/Quotation \\
\hline 1. & Tutorials & $\begin{array}{l}\text { What do you think after practicing with this module? } \\
\text { "... it's (module) helps because it shows me one by one step (step by step) ..." } \\
\text { "... the video demonstrates the real movement it is...if the space is small, and then if the colour is red for the hue } \\
\text { it is... what is it like with that hue... because I am weak in the hue so I look (video) at it a lot... " } \\
\text { "... the best this module teaches us how to do the movement, we can see that the colour that we apply near the } \\
\text { paper is even or not, there are black and white spots, so from there we can improve the blending method." }\end{array}$ \\
\hline 2. & References & $\begin{array}{l}\text { What do you think after practising with this module? } \\
\text { "... it helped me to do this near the right side (cheekbones) so that the dots are so that the cheekbones are close } \\
\text { here (as shown anatomically on the face chart), then going down is not too difficult to draw because it is part of } \\
\text { the chin, so this is the cheekbone ... it is a guide for me..." }\end{array}$ \\
\hline 3. & Module Role & $\begin{array}{l}\text { To what extent did makeup training through the module reduce your facial skin problems? } \\
\text { "... This module helps because the skin is no longer broken, it must be practised always because it is not good to } \\
\text { practise and always use make-up ingredients, it's better to do it on paper first, there are no problems with facial } \\
\text { skin ..." } \\
\text { "... If we use this module, students' faces will not be damaged, they will not have acne at all, if they start using this } \\
\text { module to make a blending, it will be easy, students will not have skin problems like acne for all ... " }\end{array}$ \\
\hline 4. & QR Code & $\begin{array}{l}\text { In your opinion, what are the benefits of the module? } \\
\text { "If you scan this code directly into the video tutorial, some module is for long notes ... then if this code (QR code) } \\
\text { is used for viewing ... then if other modules have to carry maybe one more weight ... if you look using this code it's } \\
\text { easy to understand in digital context ... if we use our books to read then don't understand ... then this module } \\
\text { scans we can find information ... if the notes can be lost. If you scan this, we can go directly to youtube ..." } \\
\text { "... this module is great because nowadays people use cellphones, so they can download applications near the } \\
\text { cellphone and scan this code, so they can see directly from the cellphone, no need to go to the computer to } \\
\text { scan ..." }\end{array}$ \\
\hline
\end{tabular}

\section{Discussion}

This study found that participants' skills in applying colour blending techniques were good. There was an increase in the participants' skills because the participants seemed comfortable and confident in applying the colour blend to the face chart after three activities. The finding shows that the blending colours activity provided participants with experience and input to improve their application of colour blending techniques. These findings indicate that the learning process exists through experience as suggested by Dale [6], D. Yosimeida and D. Lutfiati [8], N. Diana and Maspiyah [9] who stated that the learning process will be more effective if the learning activities are done on-hand (learning by doing) as learners will gather more real experiences.

Participants' skills in controlling the intensity in the application of colour blending also improved. After ongoing training, participants' skills in manipulating and controlling colour saturation increased and so did their confidence. The researchers observed that the training conducted by the participants through the application of the module had a positive effect on instilling theoretical and practical knowledge to the participants to improve their skills in colour blending techniques. These findings indicate that there is a relationship between theoretical and practical knowledge in the teaching and learning process of maquillage, and not just relying on demonstration methods. As suggested by M. Robiah and S. P. M. P. Nia Kusstianti [7], T. Yarizqi, Rostamailis, and M. Astuti [19] and S. Chendra Wibawa, S. Schulte, and I. P. Septaria [20] students with good theoretical knowledge will master the art of maquillage skills.
There is the involvement of the value attribute in determining the level of student's skills in the application of maquillage as suggested in past studies $[15,21]$. They also found that student's skills in the application of face contouring showed improvement. The results of these previous studies on the application of the value attribute to face contouring exercises through various patterns on the face chart were successfully expanded in this study in the context of colour blending skills on the face chart through the application of the module.

The findings also found that the content of the module with video tutorials that clearly shows the tread of blending techniques has facilitated students in learning maquillage skills. Besides that, the anatomical facial charts provided in the module have successfully helped students to practise applying facial maquillage. This finding shows that the concepts and activities developed in this module have helped students to learn the maquillage skills independently.

\section{Conclusions}

This research was conducted in the context of students' problems with their skills in colour blending techniques in maquillage applications. The frailty of the students' theoretical and practical knowledge due to the lecture method using demonstrations in maquillage teaching was ineffective in communicating the concept of colour blending to students. Also, this study aims to resolve disrupted teaching and learning processes due to guidelines set by WHO to prevent the spread of the COVID-19 virus. Activities in the module can be carried out by following 
these guidelines because the training process does not involve touching the facial skin and students can practise separately while maintaining the social distance between classmates. Training can also be done at home with the help of video tutorials that can be accessed via the QR code contained in the module. The continuous exercise of the 3 attributes in the colour blending technique found that the level of students' skills increased. The colour control on face chart artworks is consistent after students mastered the rhythm and concepts in colour blending techniques. The results of this study conclude that the module has played an effective role in providing training and improving student's skills. The knowledge gained by students from the module has helped students to master the technique efficiently. Thus, students' skills in maquillage can be improved through systematic, theoretical, and practical ongoing training. The development of this module can also help students continue the learning process in a safer environment and prevent students from being infected with the COVID-19 virus. Module designs with more interesting patterns can be used for future studies by other researchers. Additional art attributes and principles can also be included by other researchers. The concept of the face chart as a simulator and the video tutorial found in this module can be applied to other appropriate vocational subjects so that the teaching and learning process can continue even in the difficult COVID-19 pandemic situation.

\section{Acknowledgments}

Thank you to all those who have been very helpful and cooperative during the process of writing this article. Thanks to my family who always gave me so much time, energy and opportunity to finish this paper.

\section{REFERENCES}

[1] W. J. McKibbin and R. Fernando, "The Global Macroeconomic Impacts of COVID-19: Seven Scenarios," SSRN Electron. J., 2020.

[2] L. Zhou, S. Wu, M. Zhou, and F. Li, "'School's Out, But Class' On', The Largest Online Education in the World Today: Taking China's Practical Exploration During The COVID-19 Epidemic Prevention and Control As an Example," SSRN Electron. J., vol. 4, no. 2, pp. 501-519, 2020.

[3] "Coronavirus Disease (COVID-19) Advice For The Public," World Health Organization, 2020. [Online]. Available: https://www.who.int/emergencies/diseases/novel-coronavir us-2019/advice-for-public.

[4] H. Buchman, Film and Television Makeup, 1st editio. New York: Watson Guptill Publications, 1990.
[5] Y. A. Baltacioglu, "Three-Dimensional Makeup Education in Turkey," Procedia - Soc. Behav. Sci., vol. 51, pp. 311-315, 2012.

[6] E. Dale, Audiovisual Methods In Teaching, 3rd Editio. United States of America: The Dryden Press, 1969.

[7] M. Robiah and S. P. M. P. Nia Kusstianti, "Pelatihan Make Up Karakter Untuk Meningkatkan Keterampilan Merias Wajah Pada Ekstrakurikuler Teater Di Sma Negeri 1 Pandaan," e-Journal, vol. 05, no. 01, pp. 158-164, 2016.

[8] D. Yosimeida and D. Lutfiati, "Pelatihan corrective make up dalam meningkatkan keterampilan merias wajah korektif pada tim cheerleaders di sman 1 surabaya," e-Journal, vol. 04, no. 01, pp. 99-102, 2015.

[9] N. Diana and Maspiyah, "Penggunaan Perangkat Pelatihan Pada Pelatihan Tata Rias Wajah Dan Penataan Jilbab Bagi Santriwati Panti Asuhan Yatim," e-Journal, vol. 02, no. 03, pp. 27-32, 2013.

[10] A. M. Sevtap, "Character Design For The Players With The Professional Make-Up."

[11] L. Setiawardani and Suhartiningsih, "Pengaruh Penerapan Model Pembelajaran Berdasarkan Masalah Terhadap Hasil Belajar Rias Wajah Karakter Cacat Di Smk Negeri 6 Surabaya," e-Journal, vol. 03, no. 01, pp. 39-45, 2014.

[12] H. Didillon, D. Bounsana, and M. Vandewiele, "The 'Maquillage' Practice in Brazzaville," Psychol. Rep., vol. 62, no. 1, pp. 307-316, 1988.

[13] G. Davis and M. Hall, The Makeup Artist Handbook. USA: Elsevier Inc., 2008.

[14] V. J.-R. Kehoe, The Technique of the Professional Make-Up Artist. United States of America: Focal Press, 1995.

[15] K. Middleton, Color Theory for the Make-Up Artist: Understanding Color and Light for Beauty and Special Effects. New York: Routledge, 2018.

[16] J. Itten, The Art of Color. Germany: John Wiley \& Sons, Inc., 1970.

[17] D. Fidaleo, D., Foust, B., Neuman, J., Mallick, S., Barnes, K., \& Kriegman, "System And Method For Providing And Modifying A Personalized Face Chart," U.S. Patent No. 8,550,818, 2013.

[18] R. K. Yin, Case Study Research and Applications Design and Methods, Sixth edit. London: SAGE Publications, Inc., 2018.

[19] T. Yarizqi, Rostamailis, and M. Astuti, "Hubungan Pengetahuan Koreksi Bentuk Wajah Dengan Hasil Belajar Praktek Rias Wajah Pada Mahasiswi Angkatan 2014 Program Studi Pendidikan Tata Rias Dan Kecantikan Jurusan Kesejahteraan Keluarga Ft Unp," E-Journal Home Econ. Tour., vol. 2, no. 9, p. 19, 2015.

[20] S. Chendra Wibawa, S. Schulte, and I. P. Septaria, "Beauty Media Learning using Android Mobile Phone," Int. J. Innov. Res. Adv. Eng., vol. 11, pp. 2355-3456, 2015.

[21] R. Yuliati and M. P. Dra. Hj. Suhartiningsih, "Kompetensi Aplikasi Shading Dan Tinting Pada Make Up Koreksi Untuk Bentuk Wajah Bulat, Persegi Dan Segitiga Terbalik," e-Journal, vol. 03, no. 01, pp. 193-199, 2014. 